\begin{tabular}{|l|l|l||}
\hline \multicolumn{2}{|c|}{ PublisherInfo } \\
\hline \hline PublisherName & $:$ & BioMed Central \\
\hline \hline PublisherLocation & $:$ & London \\
\hline \hline PublisherImprintName & $:$ & BioMed Central \\
\hline \hline
\end{tabular}

\title{
Maclyn McCarty dies
}

\begin{tabular}{|l|l|l||}
\hline \multicolumn{2}{|c|}{ ArticleInfo } \\
\hline \hline ArticleID & $:$ & 5049 \\
\hline \hline ArticleDOI & $:$ & $10.1186 /$ gb-spotlight-20050111-01 \\
\hline \hline ArticleCitationID & $:$ & spotlight-20050111-01 \\
\hline \hline ArticleSequenceNumber & $:$ & 25 \\
\hline \hline ArticleCategory & $:$ & Research news \\
\hline ArticleFirstPage & $:$ & 1 \\
\hline \hline ArticleLastPage & $:$ & 3 \\
\hline \hline & & RegistrationDate : 2005-1-11 \\
\hline ArticleHistory & $:$ & OnlineDate \\
\hline \hline ArticleCopyright & $:$ & BioMed Central Ltd2005-1-11 \\
\hline \hline ArticleGrants & $:$ & \\
\hline \hline ArticleContext & $:$ & 130596611 \\
\hline \hline
\end{tabular}


Maclyn McCarty, the last surviving member of the team that proved DNA is responsible for transmitting genetic information, died January 2 of congestive heart failure. He was 93.

Colleagues agreed it was McCarty's meticulous work and strong skills in biochemistry that helped bring Oswald T. Avery's 13-year effort to identify the "transforming principle" to a convincing conclusion. "It was his key input that really turned the story around to the fact that it was this material otherwise, I think it would have taken longer to determine that," Vincent A. Fischetti, co-chair of the Laboratory of Bacterial Pathogenesis and Immunology at Rockefeller, told us. Fischetti joined McCarty's lab at Rockefeller as a technician 40 years ago.

Avery, who had been working on pneumococcus at the Rockefeller Institute for Medical Research since 1913, began searching for what he called the "transforming principle" in 1931, after being alerted to the problem by Fred Griffith's 1927 report that mice injected with a mix of heat-killed, deadly pneumococcus and a live harmless strain would die.

Avery and his team showed that simply putting dead, lethal encapsulated S (smooth) pneumococcus Type III in a Petri dish with a live, unencapsulated and harmless R (rough) strain would cause the live strain to become virulent. They conducted a series of experiments to isolate the substance responsible for transforming virulence. Colin MacLeod joined Avery's lab in 1935, while McCarty - who had just finished his residency in pediatrics at Johns Hopkins - joined in 1940 and soon began working on the problem.

By the summer of 1942, McCarty recounted in his 1985 memoir, The Transforming Principle, the convergence of several lines of research on DNA had "pretty much convinced us that in all probability it was the transforming substance." But several more months of experiments would follow until the team felt prepared to write up its research.

Avery reported the findings to Rockefeller colleagues in December 1943, and they were published in the Journal of Experimental Medicine on February 1, 1944. While many in the scientific world scoffed at the findings, based on the conventional wisdom that nucleic acids were "all the same" and much too simple to carry genetic information, at least one, Edwin Chargaff at Columbia, shifted the direction of his research to DNA.

Joshua Lederberg, who had just begun his medical studies at Columbia when he read the paper in 1945, was no skeptic. "When I heard about this work, I accepted it immediately," said Lederberg, winner of the 1958 Nobel Prize in Medicine or Physiology and professor emeritus at the Rockefeller University. "I said, 'Oh, we can do chemistry on genes,' and that determined two things for me: one, I was going to go into genetics, and two, I was going to work with bacteria."

James Watson and Francis Crick did not cite Avery, MacLeod, or McCarty in their 1953 paper describing the structure of DNA, an omission McCarty said he was "not so pleased" with in a paper he wrote for Nature in 2003 on the 50th anniversary of the discovery. In a 2003 interview, Watson said he regretted the omission. 
While McCarty and his team were nominated several times for the Nobel Prize, they never received it. "It's a universally recognized omission of the Nobel committee," John B. Robbins, a scientist at the National Institutes of Health, told us. "This was a blazing discovery that changed everything."

In 1946, McCarty became head of the Laboratory of Bacteriology and Immunology at Rockefeller and began investigating group A streptococcus and rheumatic fever. Over 40 years, he and his colleagues painstakingly identified nearly all the components of the organism's cell wall structure. McCarty also isolated and crystallized C-reactive protein, now increasingly recognized as a factor in heart disease.

McCarty was physician-in-chief at the Rockefeller University Hospital from 1960 to 1974, and became vice president of the university in 1965. He carried on bench work until becoming emeritus, in 1981. Up until his death, McCarty was senior editor of the Journal of Experimental Medicine.

\section{References}

1. Vincent A. Fischetti, [http://www.rockefeller.edu/vaf/]

2. McCarty M: The Transforming Principle: Discovering that Genes are Made of DNA, New York: WW Norton \& Company, , [http://profiles.nlm.nih.gov/CC/A/A/O/F/_ccaaof.pdf]

3. The Joshua Lederberg Papers, National Library of Medicine, [http://profiles.nlm.nih.gov/BB/]

4. Nobel Prize in Medicine or Physiology 1958, [http://nobelprize.org/medicine/laureates/1958/ index.html]

5. Nobel Prize in Medicine or Physiology 1962: James Watson - Biography, [http://nobelprize.org/ medicine/laureates/1962/watson-bio.html]

6. Moore P: Francis Crick dies Genome Biology July 30, 2004, [http://genomebiology.com/ researchnews/default.asp?arx_id=gb-spotlight-20040730-01]

7. Discovering genes are made of DNA

8. "Genes, girls and honest Jim," Bio IT World, April 15, 2003. , [http://www.bio-itworld.com/archive/ 041503/horizons_watson.html]

9. Laboratory of Developmental and Molecular Immunity, [http://dir2.nichd.nih.gov/labs/lab.php3?8]

This PDF file was created after publication. 